\title{
PHYLOGENETIC ANALYSIS OF Rhizobium STRAINS, ISOLATED FROM NODULES OF Vavilovia formosa (Stev.) Fed.
}

\section{A.K. KIMEKLIS ${ }^{1}$, V.I. SAFRONOVA ${ }^{1}$, I.G. KUZNETSOVA ${ }^{1}$, A.L. SAZANOVA ${ }^{1}$, A.A. BELIMOV ${ }^{1}$, A.G. PINAEV ${ }^{1}$, E.P. CHIZHEVSKAYA ${ }^{1}$, A.R. PUKHAEV ${ }^{2}$, K.P. POPOV ${ }^{3}$, E.E. ANDRONOV1, N.A. PROVOROV ${ }^{1}$}

\author{
${ }^{1}$ All-Russian Research Institute for Agricultural Microbiology, Federal Agency of Scientific Organizations, 3, sh. \\ Podbel'skogo, St. Petersburg, 196608 Russia, e-mail kimeklis@gmail.com; \\ ${ }^{2}$ Gorsky State Agrarian University, 37, ul. Kirova, Vladikavkaz, Republic of North Ossetia-Alania, 362040 Russia; \\ ${ }^{3}$ North-Ossetian Nature Reserve, 1, ul. Ch. Basievoi, Alagir, Republic of North Ossetia-Alania, 363240 Russia \\ Acknowledgements: \\ Supported by Russian Science Foundation (grant 14-26-00094). The equipment of ARRIAM Center for Genome \\ Technologies, Proteomics and Cell Biology (St. Petersburg) was used \\ Received July 7, 2015
}

\section{Abstract}

Among the 5 genera of tribe Fabeae, Vavilovia Fed. is the least studied consisting of the only species Vavilovia formosa (Stev.) Fed. Vavilovia's area of growth is limited by the highlands of Central and Eastern Caucasus, with only several known populations on the territories of Armenia, Dagestan, Norht Ossetia, Azerbaijan, Iran, Iraq, Siria, Turkey, and by the environmental conditions. The only phylogenetic research of rhizobia isolated from the nodules of vavilovia from the Nortn Ossetian population demonstrated significance of both slow-growing and fast-growing microsymbionts' specific and genetic diversity. It was shown that all of the fast-growing isolates, belonging to Rhizobium leguminosarum species, carry nodX gene in their genomes. Three expeditions to the regions of Armenia, Dagestan and North Ossetia succeeded in finding and collecting plants of Vavilovia formosa (Stev.) Fed. with its nodules, from which later rhizobia isolates were obtained. We have chosen nineteen fast-growing isolates, derived from ten plants' nodules, to identify their species affiliation, to trace geographical isolation and also to try to track down its genetic differences from rhizobia, which nodulate other plants of tribe Fabeae. To make this we sequenced ITS (internally transcribed spacer) fragment and nodA gene, and made screening of the isolates for the presence of nod $X$ gene, which controls rhizobia host specificity. Obtained sequences were used to calculate genetic distances between groups of rhizobia, i.e. different regions isolates (Armenia, Dagestan, North Ossetia) and isolates from different plant hosts (vavilovia, pea, clover). Results of ITS sequencing showed that all strains involved in the analysis belong to $R$. leguminosarum (bv. viciae) species. ITSdendrogram shows relatively high heterogeneity of isolates, but on nodA-dendrogram they form a very compact group. Difference in the structure of these dendrograms allows to assume that nodA gene, chained with the genes of host specificity, can be easily transferred within the populations of $R$. leguminosarum, providing unlimited combinations of specificity to vavilovia with different variants of bacterial chromosome. Comparison of genetic distances based on ITS-sequences for the isolates in this study shows tendency to geographic isolation between them. Data on nodA-based genetic distances along with the presence of nodX gene in the genomes of all $R$. leguminosarum strains in this study point out the presence of its host specificity within biovar viciae. It seems that correlation between strain origin and the genetic structure of nodA reflects presence of highly specific interactions among each group of $R$. leguminosarum strains with their plant-hosts, whereas correlations with the structure of ITS-loci reflect rhizobia adaptation to soil environment.

Keywords: Vavilovia formosa, Rhizobium leguminosarum, legume-rhizobia symbiosis.

Tribe Fabeae (син. Vicieae) is among most representative ones in the family Fabaceae Endl. It comprises over 300 species, and, however, its taxonomy is still being revised significantly. At that, many species of the tribe are of practical use in agriculture. Most ancient cultivated plants such as pea (Pisum sativum L.) and tare (Vicia sativa L.) are the representatives of this tribe [1]. Of five genera of the tribe, namely Lathyrus L., Vicia L., Lens Mill., Pisum L. and Vavilovia Fed., the last one which consists of a single species Vavilovia formosa (Stev.) Fed. remains least studied. Its areal covers the highlands of Central and 
Eastern Caucasus, and only a few populations are also known in Armenia [2], Dagestan and North Ossetia [3], Azerbaijan [4], Iran, Iraq, Syria and Turkey [5], and its vegetation is limited to conditions the environment [6], therefore, the plant itself and its microsymbionts, remained unknown for a long time.

Recently, based on phylogenetically important genes matK, trnL-F and $\operatorname{trn} S-G$, and ITS (internally transcribed spacer) fragment, the evidence was reported that the vavilovia is taxonomically close to genera Pisum and Lathyrus, being, nevertheless, clustered separately within tribe Fabeae [7]. The only reported phylogenetic study of rhizobia isolates from vavilovia nodules from North Ossetian population showed a fairly broad species abundance and genetic diversity of both fast-growing and slow-growing microsymbionts [8].

In the same study it was also found that all fast-growing isolates of $R$. leguminosarum possessed the gene nodX peculiar to the symbionts of Pisum sativum cultivar Afghanistan [9]. All known plants of tribe Fabeae are of the same cross inoculation group and can produce nodules with the bacteria of the abovementioned species, though symbiosis formation is mostly indifferent to the presence of nodX gene. Nevertheless, in the $P$. sativum cv. Afghanistan, or Afghan pea, there is $S y m 2^{A}$ allele encoding receptor specific to the Nod-factor decorated with extra acetyl group bound under the nod $X$ gene control [10].

At present, the studies of $\operatorname{nod} X$ gene role in individual interaction between a legume plant and rhizobia are fast developed [11]. Data summarized hereinabove, are enough to consider Vavilovia formosa and its microsymbiont a promising model in revealing mechanisms of specificity evolution in the legumerhizobia symbiosis.

Due to our successful expeditions to Caucasian territories, the samples of Vavilovia formosa have been collected, and rhizobia from the plant nodules were isolated.

In this research, the fast-growing rhizobia isolates from Vavilovia formosa nodules were taxonomically attributed based on analysis of ITS region sequences, and their host specificity was studied by phylogenetic analysis of nodA and $\operatorname{nod} X$ genes. Additionally, the genetic distances in rhizobia isolated from different host plants of distinct locations were compared with regard to ITS and $\operatorname{nod} A$ sequences to estimate the environmentally important polymorphic parameters in studied isolates.

Technique. Nodulated vavilovia plants were collected in 2012-2013 in North Ossetinian Reserve (North Ossetia, Alagirskii Region), Armenia and Dagestan at more than $1,500 \mathrm{~m}$ above see level. Of total, 19 rhizobia strains isolated from 10 plants of three different populations were studied.

For rhizobia isolation we used common procedures [12]. From each nodule a strain was isolated and further grown on the media № 79 [13] at $28{ }^{\circ} \mathrm{C}$. All isolated have been deposited to the ARRIAM Russian collection of agricultural microorganisms and stored at Station of Low Temperature Automated Storage of Biological Samples at $-80^{\circ} \mathrm{C}$ (Liconic Instruments, Lichtenstein) [14]. Data are available online at http://www.arriam.spb.ru).

Bacterial DNA was isolated according to standard protocol [15], and 1,000-1,300 bp ITS fragment (intergenic transcribed spacer) was amplified using primers FGPS1490-72 5'-TGCGGCTGGATCCCCTCCTT-3' and FGPL132'-38 5'-CCGGGTTTCCCCATTCGG-3' [16, 17]. The nodA gene 66 bp fragment was analyzed with primers nodA-1 5'-GCRGTGGAARNTRN-NCTGGGAAA-3' and nodA-2 5'-GGNCCGTCRTCRAASGTCARGTA-3' [18]. The PCR mixture $(25 \mu \mathrm{l})$ contained $150 \mu \mathrm{M}$ dNTPs (Helicon, Russia), $1 \mathrm{U}$ Taq-polymerase (Eurogen, Russia), $10 \mathrm{pM}$ of each primers and 10-20 ng of purified DNA as matrix. Amplification was performed at a T100 amplifier (Bio-Rad, USA) as follows: ini- 
tial denaturation at $95{ }^{\circ} \mathrm{C}$ for 2 minutes; 35 cycles comprising denaturation at $94{ }^{\circ} \mathrm{C}$ for 30 seconds, annealing at $50{ }^{\circ} \mathrm{C}$ with FGPS1490-72/FGPL132'-38 primers or at $49{ }^{\circ} \mathrm{C}$ with nodA-1/nodA-2 primers for 30 seconds, elongation at $72{ }^{\circ} \mathrm{C}$ for 1 minute; final elongation at $72{ }^{\circ} \mathrm{C}$ for 3 minutes.. PCR fragments were separated electroforetically in $1 \%$ agarose gel (Amresco, USA) with 0,5× TAE, with DNA molecular weigh marker $100 \mathrm{bp}+1,5 \mathrm{~Kb}+3 \mathrm{~Kb}$ (Sibenzyme, Russia). PCR products were purified as described [19]. ITS region and nodA gene were sequenced on a ABI PRISM 3500xl genetic analyzer (Applied Biosystems, USA), with UGENE program (Unipro, Russia) for primary data processing [20]. The similarity was found by BLAST analysis using GeneBank database (http://www.ncbi.nlm.nih.gov/). The obtained data were used to design two dendrograms by joint neighbor method (MEGA v. 5.0) [21]. Evolution distances were evaluated by p-distance technique. A bootstrap analysis for 1,000 random samples was used for reliable clustering.

The $\operatorname{nod} X$ gene in isolated was detected in PCR with primers oMP199-F 5'-CCATGGGACCATCCAATGAAC-3' and oMP196-R 5'-TTAAGCGACGGAAAGCCTTC-3' [22]. The PCR mix composition and protocol was the same as described hereinabove except annealing at $53{ }^{\circ} \mathrm{C}$. $R$. leguminosarum bv. viciae A1 strain [22] producing nodules with Afghan pea plants was a positive control.

Genetic distances were calculated for ITS fragments and nodA genes for each taxonomic and geographically distant group of rhizobia the same as between these groups. A genetic distance as estimated on ITS region and $\operatorname{nodA}$ gene sequences was compared in two distinct groups of microorganisma. The first one comprised $R$. leguminosarum bv. viciae (pea rhizobia), $R$. leguminosarum bv. trifolii (clover rhizobia) and tested isolated with correlation to host specificity, and the second one consisted of vavilovia isolated as correlated to geografic origin. We compared genetic distances both within and between the groups. The $\mathrm{p}$ distance parameter estimated using MEGA v. 5.0 [21].

Results. ITS fragments were amplified and sequenced, partially or completely, in all tested isolated, and in Dagestanian isolates there were at least two different copies of ribosomal operon with ITS fragments of different size. In the dendrogram based on ITS sequencing (Fig. 1) these sequences are marker as 1 (long) and s (short).

In the Table 1 we indicated the size of amplified fragments and their homology to ITS sequence of typical strains of $R$. leguminosarum species of which TOM strain possesses nodX gene. Genomes of these strains are sequenced and available online in the NCBI database. Note, with regard to ITS, strains isolated from vavilovia nodules are similar to viciae biovar rather than to trifolii biovar, so far as an average similarity coefficient was $83 \pm 0.9 \%$ in strain 3841 , $89 \pm 0.8 \%$ in strain TOM and only $80 \pm 1.0 \%$ in strain WSM2304.

1. Origin of strains isolated from vavilovia Vavilovia formosa (Stev.) Fed. nodules and similarity of their ITS regions to referent strains sequences deposited in GenBank

\begin{tabular}{|c|c|c|c|c|c|c|}
\hline \multirow[b]{2}{*}{ Strain } & \multirow[b]{2}{*}{ Plant № } & \multirow{2}{*}{$\begin{array}{l}\text { ITS frag- } \\
\text { ment size, } \\
\text { np }\end{array}$} & \multicolumn{4}{|c|}{ Similarity, \% } \\
\hline & & & $\begin{array}{l}\text { Rhizobium legumino- } \\
\text { sarum bv. viciae } 3841\end{array}$ & $\begin{array}{l}\text { Rhizobium } \\
\text { sarum bv. I }\end{array}$ & $\begin{array}{l}\text { legumino- } \\
\text { viciae TOM }\end{array}$ & $\begin{array}{l}\text { Rhizobium leguminosa- } \\
\text { rum bv. trifolii WSM2304 }\end{array}$ \\
\hline \multicolumn{7}{|c|}{ North Ossetia } \\
\hline Vaf-01 & 1 & 565 & 96 & & 86 & 90 \\
\hline Vaf-09 & & 613 & 75 & & 90 & 75 \\
\hline Vaf-10 & 3 & 1206 & 83 & & 95 & 81 \\
\hline Vaf-12 & & 1184 & 85 & & 89 & 88 \\
\hline Vaf-23 & 4 & 565 & 99 & & 88 & 100 \\
\hline Vaf-25 & & 649 & 80 & & 99 & 72 \\
\hline Vaf-26 & 5 & 1113 & 91 & & 94 & 91 \\
\hline
\end{tabular}




\begin{tabular}{|c|c|c|c|c|c|}
\hline \multicolumn{6}{|c|}{ Armenia } \\
\hline \multirow{2}{*}{ Vaf-45 } & 7 & 1199 & 82 & 93 & 80 \\
\hline & & 1010 & 78 & 90 & 79 \\
\hline \multirow[t]{2}{*}{ Vaf-72 } & & 1199 & 82 & 93 & 80 \\
\hline & & 1010 & 78 & 90 & 79 \\
\hline \multirow[t]{2}{*}{ Vaf-46 } & 8 & 1199 & 82 & 93 & 80 \\
\hline & & 1010 & 78 & 90 & 79 \\
\hline \multirow[t]{2}{*}{ Vaf-51 } & & 1199 & 82 & 93 & 80 \\
\hline & & 1010 & 78 & 90 & 79 \\
\hline \multicolumn{6}{|c|}{ Dagestan } \\
\hline VD1/1k & 1D & 1105 & 92 & 86 & 87 \\
\hline $\mathrm{VD} 1 / 9 \mathrm{~m}$ & & 1287 & 86 & 94 & 75 \\
\hline VD3/2(1) & $3 \mathrm{D}$ & 1032 & 82 & 83 & 77 \\
\hline VD3/7k & & 1032 & 82 & 83 & 77 \\
\hline VD6/12k & $6 \mathrm{D}$ & 1032 & 82 & 83 & 77 \\
\hline VD6/13m & & 1032 & 82 & 83 & 77 \\
\hline VD7/1 & $7 \mathrm{D}$ & 1032 & 82 & 83 & 77 \\
\hline VD7/20m & & 1032 & 82 & 83 & 77 \\
\hline
\end{tabular}

ITS dendrogram showed that all tested strains was attributed to family Rhizobiaceae and clustered into two groups of bacterial species with different types of ribosomal operon (the clusters I and II). Moreover, strains were grouped with no regard to taxonomic attribution or geographical prevalence. $R$. leguminosarum bv. viciae, $R$. leguminosarum bv. trifolii, and $R$. etli, the same as different vaviolovia isolates from Armenia and Dagestan were representatives of both groups. It probably could be due to only few chromosome types providing adaptation to environmental conditions and viability in bacteria.

Rhizobia isolated from vavilovia nodules did not form an individual cluster, and separated into groups demonstrating tendency to geographical isolation in the tested microorganisms. All Armenian strains, the same as 6 of 8 strains from Dagestan, were clustered at high statistical level $(>82 \%)$ in group I. ITS fragments of vavilovia strains from North Ossetia was found only in group II and clustered along with strains from the same territory (Vaf-01 and Vaf-12, Vaf-09 and Vaf-10, Vaf-23 and Vaf-26). Vaf-25 strain was the only exception and grouped at $87 \%$ bootstrap level to strains VD1/9m from Dagestan and $R$. leguminosarum bv. viciae TOM with nodX gene. Similar clusterization pattern we observed earlier in North Ossetinian isolates [8]. Therefore, it was reasonable to study whether there was $\operatorname{nod} X$ gene in the isolates from Armenia and Dagestan (Fig. 2), and it was found it all tested isolates.

Importantly, the ITS sequence, being the core part of the genome, allows us to understand only the taxonomic attribution of the stains whereas host specificity can be understood only from studying genes involved in formation of legume-rhizobia symbiosis. These are the genes of nod operons [23]. So we studied $\operatorname{nod} A$ gene. Though $\operatorname{nod} A$ gene does not control the symbiotic specificity directly, it is linked to genes encoding factors which provide host specificity. This gene is convenient to study due to a single copy in the rhizobia genome [18]. ITS and nod $A$ based dendrograms differed sufficiently (Fig. 1, 3). In the nod $A$ dendrogram, all isolates clustered with $R$. leguminosarum bv. viciae strains at $100 \%$ statistical level. Thus, these isolates may be considered the rhizobia of the pea cross inoculation group. Based on nodA gene analysis, the isolates of this cluster were divided into three groups which did not coincide with ITS groups. In this, the isolates from North Ossetia and Dagestan clustered together into groups I and III, while Armenian isolates were found only in group II (see Fig. 3). It should be noted that in the nodA dendrogram the strain $R$. leguminosarum bv. viciae TOM was most closely related to the studied isolated. The strains from other taxones were not found in all three clusters comprising vavilovia isolates, that may be 
consider an additional evidence toward isolation of these strains.

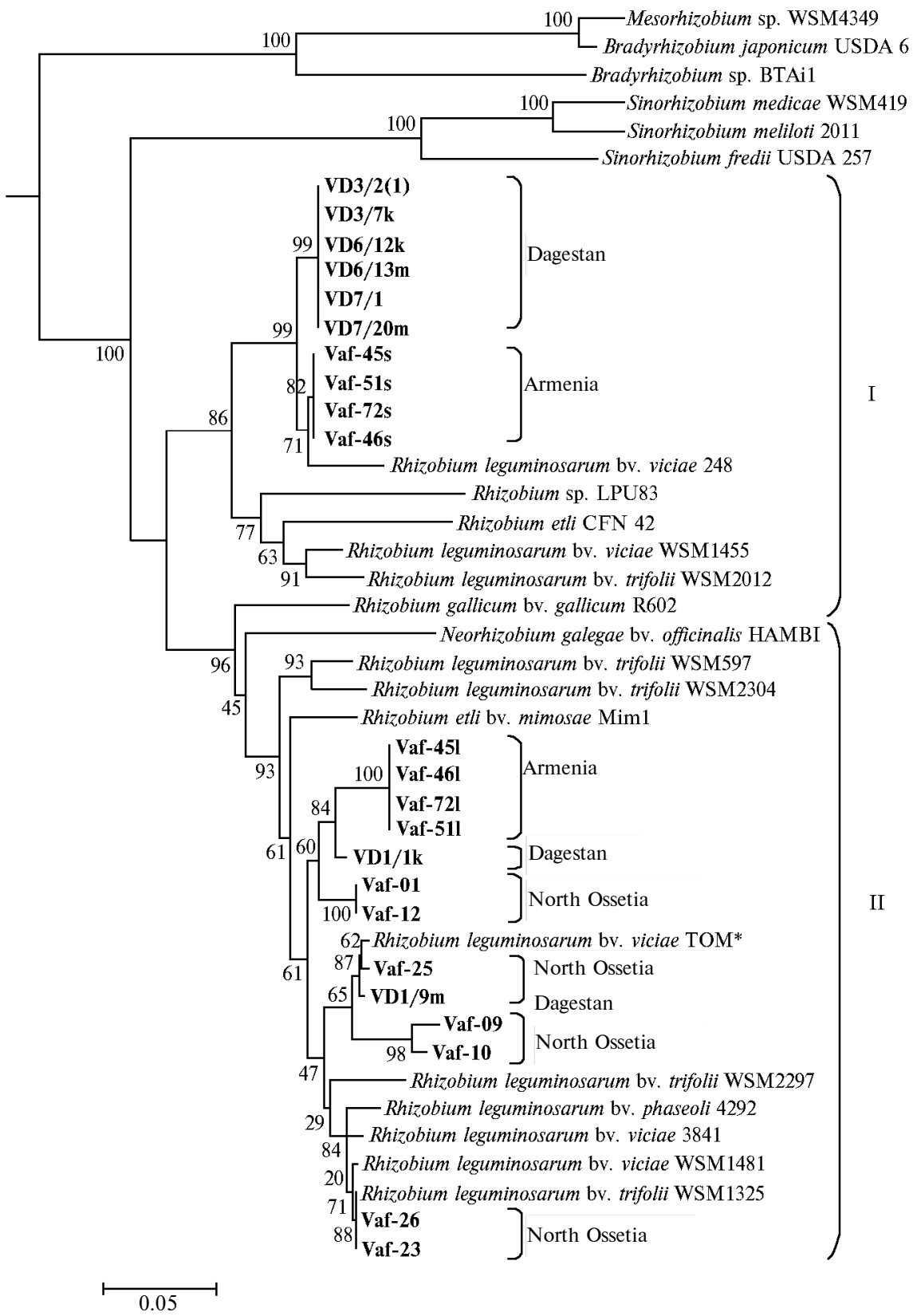

Fig. 1. Dendrogram based on ITS (758 bp) sequences in rhizobia strains isolated from Vavilovia formosa (Stev.) Fed. plants depending on geographical origin. Strains are grouped by the «neighborjoining» method. Phylogenetic tree of the isolates reflects their taxononomy. Bootstrap value $>45 \%$ for 1,000 random samples are show. I and II are statistically reliable clusters. Strain with $\operatorname{nod} X$ gene is marked (*); s (short) and 1 (long) are Armenian strains with different copies of ITS fragments. Studied strains are mark bold.

In different groups of rhizobia no relationship with host specificity was traced based on ITS fragment sequencing analysis, since genetic distance within the groups was statistically indistinguishable from that between the groups (Table 2). Thus, more reasonably, there is a tendency to geographical isolation of the vaviolovia microsymbionts involved in our study. 
2. Genetic distance on ITS and nodA gene sequences in rhizobia isolated from different host plants depending on geographical origin

\begin{tabular}{|c|c|c|}
\hline \multirow{2}{*}{ Strain, origin } & \multicolumn{2}{|c|}{ Genetic distance } \\
\hline & ITS & $\operatorname{nod} A$ \\
\hline \multicolumn{3}{|c|}{ Correlation to host plant } \\
\hline \multicolumn{3}{|l|}{ As compared within group: } \\
\hline from vavilovia (Rhizobium leguminosarum bv. viciae) & $0.082 \pm 0.008$ & $0.036 \pm 0.005$ \\
\hline from pea (Rhizobium leguminosarum bv. viciae) & $0.115 \pm 0.010$ & $0.016 \pm 0.003$ \\
\hline from clover ( $R$. leguminosarum bv. trifolii) & $0.089 \pm 0.008$ & $0.119 \pm 0.010$ \\
\hline \multicolumn{3}{|l|}{ As compared between groups: } \\
\hline vavilovia-pea & $0.096 \pm 0.008$ & $0.045 \pm 0.006$ \\
\hline vavilovia - clover & $0.099 \pm 0.008$ & $0.252 \pm 0.015$ \\
\hline pea-clover & $0.100 \pm 0.008$ & $0.254 \pm 0.016$ \\
\hline Correlation to ge & eographical origin & \\
\hline \multicolumn{3}{|l|}{ As compared within group: } \\
\hline Armenia & $0.000 \pm 0.000$ & $0.001 \pm 0.001$ \\
\hline Armenia & $0.054 \pm 0.007$ & $0.040 \pm 0.005$ \\
\hline North Ossetia & $0.050 \pm 0.006$ & $0.040 \pm 0.005$ \\
\hline \multicolumn{3}{|l|}{ As compared between groups: } \\
\hline Armenia - Armenia & $0.116 \pm 0.012$ & $0.039 \pm 0.006$ \\
\hline Armenia - North Ossetia & $0.060 \pm 0.007$ & $0.039 \pm 0.006$ \\
\hline Armenia - North Ossetia & $0.111 \pm 0.011$ & $0.034 \pm 0.005$ \\
\hline
\end{tabular}

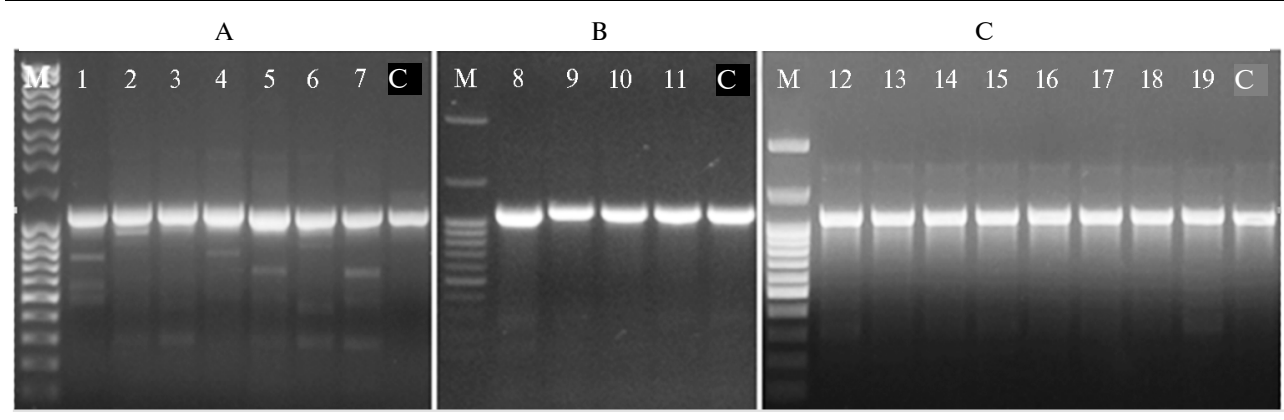

Fig. 2. PCR analysis of rhizobia isolated from Vavilovia formosa (Stev.) Fed. in North Ossetia (A), Armenia (B) and Dagestan (C) with primers omP196/omP199: 1 - Vaf-01, 2 - Vaf-09, 3 - Vaf10, 4 - Vaf-12, 5 - Vaf-23, 6 - Vaf-25, 7 - Vaf-26, 8 - Vaf-45, 9 - Vaf-72, 10 - Vaf-46, 11 Vaf-51, 12 - VD1/1k, 13 - VD1/9m, 14 - VD3/2(1), 15 - VD3/7k, 16 - VD6/12k, $17-$ VD6/13m, 18 - VD7/1, 19 - VD7/20m. DNA of Rhizobium leguminosarum bv. viciae A1 was used as control (C). Molecular weight marker (M) is MassRuler (Thermo Scientific, USA) (A) и $100 \mathrm{bp}+1.5 \mathrm{~Kb}+3 \mathrm{~Kb}$ (Sibenzyme, Russia) (B, C).

Nevertheless, in the genetic distance assessment based on the nodA gene sequence homology, clear correlation to the host specificity was disclosed though no relationship to the geographical origin of vavilovia plants was found. The $\operatorname{nod} A$ gene determines binding fatty acid residue to oligochitin chain which is common in the Nod-factor synthesis for all rhizobia, therefore, the observed correlation is probably due to nodA linkage to the host specificity genes. In $R$. leguminosarum these genes are grouped as compact clusters of about $20,000 \mathrm{bp}$ in size on the Sym-plasmids. The revealed correlation seems to reflect the fact of high specific interactions between each group of $R$. leguminosarum strains and the corresponding host plants.

Because of no similarity in nodA and ITS based dendrogram patterns, it is reasonably to assume an easy exchange of the plasmid-located nod-genes in $R$. leguminosarum populations which provides free combination of the bacterial genes of host specificity to vavilovia and different types of bacterial chromosomes in biovar viciae and, in some cases, in biovar trifolii,. This is evidenced by $100 \%$ homology of ITS region in one vavilovia rhizobial isolate of those involved in our investigation and in a representative strain WSM2304, being in line with earlier reported probability of active Sym-plasmids transfer between mentioned biovars in nature. 
100] Bradyrhizobium japonicum USDA 6

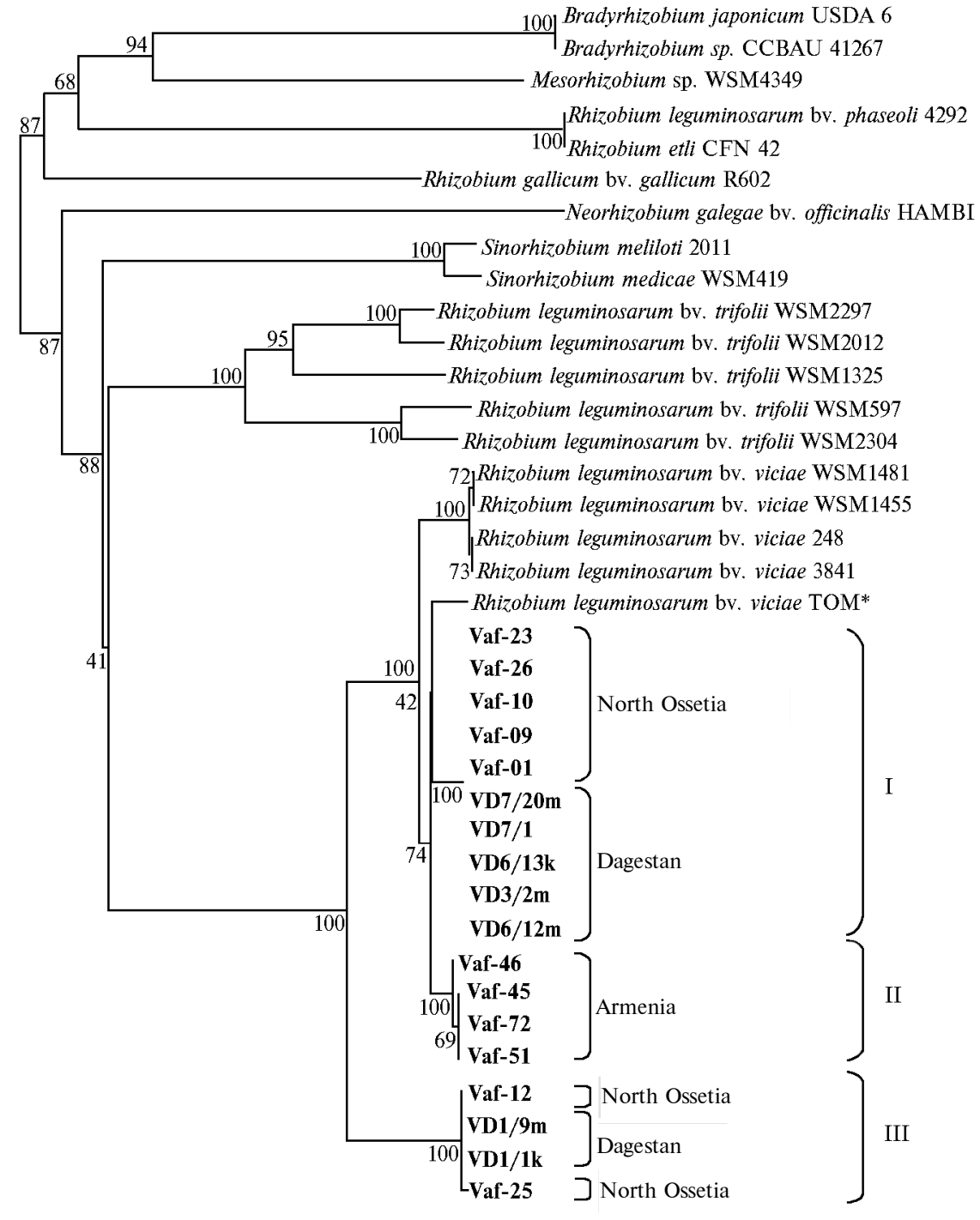

0.05

Puc. 3. Dendrogram based on nodA (531 bp) sequence in rhizobia strains isolated from Vavilovia formosa (Stev.) Fed. plants depending on geographical origin. Strains are grouped by the «neighborjoining» method. Phylogenetic tree of the isolates reflects their taxononomy. Bootstrap value $>45 \%$ for 1,000 random samples are show. I, II and II are statistically reliable clusters. Strain with nodX gene is marked $(*)$. Studied strains are marked bold.

Thus, from ITS sequencing analysis, all rhizobia strains isolated from Vavilovia formosa (Stev.) Fed. nodules and involved in our investigation were taxonomically attributed to Rhizobium leguminosarum. Moreover, taking into account the phylogenetic analysis of both ITS region and nodA gene sequences, it is possible to attribute these strains to the boivar viciae. According to the calculated genetic distances, all these isolates form a distinct statistically separated group in which a tendency to geographical isolation and strict host specificity is traced. Grouping $R$. leguminosarum bv. viciae strains into clusters separately from other strains, and disclosing Afghan pea nodulation gene nodX in all isolates from Vavilovia formosa can be basic for further study of these rhizobia group in the view to its possible attribution as an individual taxonomic group of $R$. leguminosarum species. 


\section{R E F E R E N C E S}

1. Lju šti na M., Miki A. Archaeological evidence for the domestication of lentil (Lens culinaris) and its distribution in Europe. J. Lentil Res., 2010, 4: 26-29.

2. G a b ri e ly a n E.T. Rod Vavilovia Fed. V knige: Flora Armenii. Tom 4 /Pod redaktsiei A.L. Takhtadzhyana [Flora of Armenia. V. 4. A.L. Takhtadzhyzn (ed.)]. AN SSR Armeniya, Erevan, 1962.

3. D z y u b e n k o N.I., D z y u b e n k o E.A. Vavilovia formosa (Stev.) An. Fed. Agroekologicheskii atlas Rossii i sopredel'nykh stran: ekonomicheski znachimye rasteniya, ikh vrediteli, bolezni $i$ sornye rasteniya / Pod redaktsiei A.N. Afonina, S.L. Grina, N.I. Dzyubenko, A.N. Frolova. [Online Agroecological atlas of Russia and neighbouring countries: economic plants, and their pests, weeds and diseases. A.N. Afonin, S.L. Grin, N.I. Dzyubenko, A.N. Frolov (eds.)] 2008 (online http://www.agroatlas.ru/ru/content/related/Vavilovia_formosa/).

4. K a ry a gi n I.I. Flora Azerbaidzhana. Tom 5 [Flora of Azerbaijan. V. 5]. Baku, 1954.

5. M axt e d N., A m b ros e M. Peas (Pisum L.). In: Plant genetic resources of legumes in the Mediterranean /N. Maxted, S.J. Bennett (eds.). Kluwer, Dordrecht, 2001.

6. Makasheva R.K., Drozd A.M., Ad a mova O.P., Golubev A.A. Perennial pea. Bull. Appl. Bot. Gen. Plant Breed., 1973, 51: 44-56.

7. K e n i c e r G., S m ýk a l P., V i s h y a k ov a M., M i k i ć A. Vavilovia formosa, an intriguing Pisum relative. Grain Legumes, 2009, 51: 8-12.

8. S afronova V.I., Ki mek 1 is A.K., Chizhevskaya E.P., B eli mov A.A., An dronov E.E., Pinaev A.G., Pukhaev A.R., Popov K.P., Tikhonovich I.A. Genetic diversity of rhizobia isolated from nodules of the relic species Vavilovia formosa (Stev.) Fed. Antonie van Leeuwenhoek, 2014, 105: 389-399 (doi: 10.1007/s10482-013-0089-9).

9. M a S.W., I y e $\mathrm{r}$ V.N. New field isolates of Rhizobium leguminosarum biovar viciae that nodulate the primitive pea cultivar Afghanistan in addition to modern cultivars. Appl. Environ. Microbiol., 1990, 56: 2206-2212.

10. Kozik A., Heidstra R., Horvath B., Kulikova O., Tikhonovich I., E1lis T.H.N., va n Kammen A., Li e T.A., B is se $\mathrm{ling}$ T. Pea lines carrying syml or sym2 can be nodulated by Rhizobium strains containing nodX; sym1 and sym2 are allelic. Plant Sci., 1995, 108: 41-49 (doi: 10.1016/0168-9452(95)04123-C).

11. Zhukov V., Radutoiu S., Madsen L.H., Rychagova T., Ovchinnikova E., Borisov A., Tikhonovich I., Stougaard J. The pea Sym37 receptor kinase gene controls infection-thread initiation and nodule development. MPMI, 2008, 21(12): 1600-1608 (doi: 10.1094/MPMI-21-12-1600).

12. Novik ova N., S a f r o n o va V. Transconjugants of Agrobacterium radiobacter harbouring sym genes of Rhizobium galegae can form an effective symbiosis with Medicago sativa. FEMS Microbiol Lett., 1992, 93: 261-268 (doi: 10.1111/j.1574-6968.1992.tb05107.x).

13. Alle n O.N. Experiments in soil bacteriology. Burgess Publishing Co., Minneapolis, $3^{\mathrm{d}}$ ed., 1959: 117.

14. Safronova V.I., Tikhonovich I.A. Automated cryobank of microorganisms: Unique possibilities for long-term authorized depositing of commercial microbial strains. In: Microbes in applied research: current advances and challenges /A. Mendez-Vilas (ed.). World Scientific Publishing Co., 2012: 331-334 (doi: 10.1142/9789814405041_0066).

15. Rumyantseva M.L., Simarov B.V., Onishc $\bar{h} u k$ O.P., Andronov E.E., $\mathrm{Ch}$ i zhevskay a E.P., B e lova V.S., Kurchak O.N. Biologicheskoe raznoobrazie kluben'kovykh bakterii $v$ ekosistemakh $i$ agrotsenozakh: teoreticheskie osnovy $i$ metody [Biodiversity of rhizobia in ecosystems and agrocenoses: theoretical bases and methods]. St. Petersburg-Pushkin, 2011.

16. Normand P., Po n so n net C., Nesme X., N e y r a M., S i mo net P. ITS analysis of prokaryotes. In: Molecular microbial ecology manual /A.D.L. Akkermans, J.D. van Elsas, F.J. de Bruijn (eds.). Kluwer Academic Publishers, Dordrecht, Netherlands, 1996: 1-12.

17. Pons o n net C., Nes me X. Identification of Agrobacterium strains by PCR-RFLP analysis of pTi and chromosomal regions. Arch. Microbiol., 1994, 161: 300-309 (doi: 10.1007/BF00303584).

18. Ha k k a K., Lind strom K., Young J.P. Three phylogenetic groups of nodA and nifH genes in Sinorhizobium and Mesorhizobium isolates from leguminous trees growing in Africa and Latin America. Appl. Environ. Microbiol., 1998, 64: 419-426.

19. Andronov E.E., Pinaev A.G., Pershina E.V., Chizhevskaya E.P. Nauchnometodicheskie rekomendatsii po vydeleniyu vysokoochishchennykh preparatov DNK iz ob"ektov okruzhayushchei sredy [Recommendations on highly purified DNAs isolation from environmental objects]. St. Petersburg, 2011.

20. Okonechnikov K., Golosova O., Fursov M., the UGENE team. Unipro UGENE: a unified bioinformatics toolkit. Bioinformatics, 2012, 28: 1166-1167 (doi: 10.1093/bioinformatics/bts091). 
21. Tamura K., Peterson D., Peterson N., Stecher G., Nei M., Kumar S. MEGA5: Molecular evolutionary genetics analysis using maximum likelihood, evolutionary distance, and maximum parsimony methods. Mol. Biol. Evol., 2011, 28: 2731-2739 (doi: 10.1093/molbev/msr121).

22. Ovtsyna A.O., Rademaker G.-J., Esser E., Weinman J., Rolfe B.G., Tikhonovich I.A., Lugtenberg B.J.J., Thomas-Oates J.E., Spaink H.P. Comparison of characteristics of the nodX genes from various Rhizobium leguminosarum strains. MPMI, 1999, 12: 252-258 (doi: 10.1094/MPMI.1999.12.3.252).

23. Laguerre G., Nour S.M., Macheret V., Sanjuan J., Drouin P., Amarg e $\mathrm{r}$ N. Classification of rhizobia based on nod C and nifH gene analysis reveals a close phylogenetic relationship among Phaseolus vulgaris symbionts. Microbiology, 2001, 147: 981-993 (doi: 10.1099/00221287-147-4-981). 